\title{
SPARCL1 wt Allele
}

National Cancer Institute

\section{Source}

National Cancer Institute. SPARCL1 wt Allele. NCI Thesaurus. Code C106065.

Human SPARCL1 wild-type allele is located in the vicinity of $4 \mathrm{q} 22.1$ and is approximately $58 \mathrm{~kb}$ in leng th. This allele, which encodes SPARC-like protein 1, may play a role in both endothelium structure and leukocyte migration. 